\title{
Accessibility assessment of selected university websites
}

\section{Ocena dostępności wybranych serwisów uczelni wyższych}

\author{
Wojciech Stasiak*, Mariusz Dzieńkowski \\ Department of Computer Science, Lublin University of Technology, Nadbystrzycka 36B, 20-618 Lublin, Poland
}

\begin{abstract}
The accessibility of websites consists in ensuring the possibility of using the information posted there by all users, especially by disabled people. The aim of the study was to examine the levels of accessibility of websites of Lublin universities and to compare them with the websites of two universities in Poland selected for the purpose of the study. With this aim in view, an experiment was developed, which consisted of two parts. In the first part of the experiment, a specially made original checklist was used containing questions about specific functionalities of websites corresponding to important accessibility issues. In the second part, automated tools were used with a view to assessing the accessibility. The research material consisted of eight websites of universities from Lublin and two websites of universities from other cities in Poland that were compared in the study. Those two universities in contrast to the eight ones additionally had special sets of websites for people with disabilities. Such additional sets of websites specifically designed for the needs of people with disabilities were also included in the research. After conducting the experiment, it was possible to identify the universities which have the best and the worst websites in terms of accessibility results. Furthermore, the study revealed specific pages of these websites that were characterized by the highest and the lowest average accessibility ratings. The results of the expert analysis showed that the examined university websites do not have an attached declaration of accessibility, contain documents in the PDF format that are not accessible, often do not allow for changes of colour and do not have a mobile version.
\end{abstract}

Keywords: website accessibility; accessibility evaluation; web accessibility testing techniques; accessibility automated tools

\section{Streszczenie}

Dostępność stron internetowych polega na zapewnieniu możliwości korzystania z informacji tam zamieszczonych przez wszystkich użytkowników, a zwłaszcza przez osoby niepełnosprawne. Celem pracy było zbadanie poziomów dostępności serwisów internetowych uczelni wyższych Lublina i porównanie ich z serwisami dwóch uczelni w Polsce wybranych na potrzeby tego badania. W tym celu opracowano eksperyment, który składał się z dwóch części. W pierwszej części eksperymentu zastosowano autorską listę kontrolną zawierającą pytania dotyczące określonych funkcjonalności serwisów odpowiadających istotnym kwestiom dostępności. W drugiej części do oceny dostępności wykorzystano automatyczne narzędzia. Materiałem badawczym było osiem serwisów uczelni z Lublina oraz dwóch zestawionych z nimi uczelni w innych miastach w Polsce. Uczelnie te dodatkowo posiadały w swoich serwisach specjalnie wydzielone zestawy stron dla osób z niepełnosprawnościami. Takie dodatkowe strony opracowane specjalnie dla potrzeb osób niepełnosprawnych zostały także uwzględnione w badaniach. Po przeprowadzeniu eksperymentu możliwe było wskazanie uczelni, które posiadają najlepsze i najgorsze serwisy pod względem osiąganych wyników dostępności. Dodatkowo badania wyłoniły konkretne strony tych serwisów, które charakteryzowały się najwyższymi i najniższymi średnimi ocenami dostępności. W wyniku analizy eksperckiej okazało się, że niektóre z przebadanych serwisów uczelni nie mają dołączonej deklaracji dostępności, zawierają dokumenty w formacie PDF, które nie są dostępne, często nie umożliwiają zmiany kolorystyki oraz nie posiadają wersji mobilnej.

Słowa kluczowe: dostępność stron internetowych; metody badania dostępności stron www; automatyczne narzędzia do testowania dostępności

\author{
*Corresponding author \\ Email address: wojciech.stasiak@pollub.edu.pl (W. Stasiak)
}

CPublished under Creative Common License (CC BY-SA v4.0)

\section{Wstęp}

Dostępność jest cechą stron internetowych oznaczającą, że zawarte $w$ nich treści za sprawą wbudowanych mechanizmów są dostępne dla możliwie największej grupy odbiorców [1]. Właściwość ta ma umożliwiać wszystkim osobom, a szczególnie osobom z niepełnosprawnościami odbieranie informacji, zrozumienie informacji, nawigowanie po dostępnych danych oraz wchodzenie w interakcje $\mathrm{z}$ siecią [2]. Konieczność zapewnienia dostępności wynika z przesłanek biznesowych, a więc z chęci poszerzenia grona potencjalnych użytkowników oraz $\mathrm{z}$ uregulowań prawnych związanych $\mathrm{z}$ polityką równości $w$ dostępie do informacji [1]. We wszystkich wiodących dokumentach Unii Europejskiej zawarte są wymagania niedyskryminacji w dostępie do danych, zwłaszcza tych publicznych [1]. W Polsce wiele aktów prawnych gwarantuje równość w dostępie do informacji. Należą do nich Konstytucja RP, ustawy „o dostępie do informacji publicznej” oraz „o informatyzacji działalności podmiotów realizujących zadania publiczne" [3]. 
W 2016 roku ukazała się dyrektywa 2016/2102 przygotowana przez Parlament Europejski i Radę Unii Europejskiej mówiąca o dostępności stron internetowych i mobilnych aplikacji sektora publicznego zobowiązująca kraje członkowskie do uchwalenia prawa zgodnego z normą EN 301 549, zawierającego wytyczne standardu WCAG na poziomie AA [4]. W związku z tym Rząd Polski przygotował i 4 kwietnia 2019 r. opublikował ustawę o dostępności cyfrowej stron internetowych i aplikacji mobilnych podmiotów publicznych, wprowadzającą takie normy w życie. Przepisy te mówią o obowiązku dostępności cyfrowej, obowiązku umieszczenia deklaracji dostępności, opisują zasady monitorowania dostępności cyfrowej i zasady postępowania w przypadku braku tej dostępności [5].

Publiczne uczelnie wyższe, podobnie jak inne instytucje publiczne, których strony zostały opublikowane przed 23 września 2018 r. zostały zobligowane do dostosowania swoich serwisów do 23 września 2020 roku [6] do standardu WCAG 2.1 na poziomie AA. Uczelnie niepubliczne, nie muszą formalnie spełniać wymogów w zakresie dostępności ich zawartości, ale jest to w ich interesie biznesowym.

Celem niniejszej pracy jest przedstawienie oraz zastosowanie hybrydowej metody oceny dostępności opartej na manualnym sprawdzeniu serwisu przez ekspertów oraz wykorzystującej narzędzia automatyczne do oceny poziomu dostępności serwisów internetowych uczelni publicznych i niepublicznych Lublina w zestawieniu $\mathrm{z}$ dwoma uczelniami w Polsce wybranymi dla celów badawczych tej pracy.

\section{Przegląd literatury}

Dostępność serwisów internetowych wiąże się z dwoma nierozerwalnymi aspektami: informacyjnym $\mathrm{i}$ technicznym. Nawet serwis zbudowany jak najlepiej pod względem technicznym, może zawierać informacje, które nie będą dostępne. Także wytwarzanie i publikowanie dostępnych treści bez zapewnienia technicznych rozwiązań w zakresie dostępności może skutkować tym, że strona www nie będzie dostępna [7].

Na dostępność serwisów internetowych, oprócz treści i oprogramowania do prezentacji zawartości www, mają również technologie wspierające (np. czytnik ekranu, specjalne klawiatury, przełączniki, ekranowe lupy), wiedza i doświadczenie odbiorców, świadomość i kompetencje projektantów i twórców serwisów, narzędzia do budowania serwisów oraz narzędzia do ich oceny [8].

Istotnymi dokumentami określającymi dostępność serwisów internetowych są różnego typu standardy. Wśród nich należy wymienić standardy opracowane przez konsorcjum W3C (ang. World Wide Web Consortium), standardy amerykańskie oraz brytyjskie. Utworzona w ramach W3C grupa WAI (ang. Web Accessibility Initiative), zajmująca się $\mathrm{W}$ promowaniem standardów służących poprawie dostępności usług internetowych dla osób niepełnosprawnych i wykluczonych cyfrowo, opracowała szereg dokumentów związanych $\mathrm{z}$ dostępnością stron www. Zawierają one m.in. zalece- nia dla oprogramowania służącego do tworzenia stron internetowych ATAG (ang. Authoring Tool Accessibility Guidelines), zbiory zasad dotyczących dostępności narzędzi wspomagających użytkowników UAAG (ang. User Agent Accessibility Guidelines), wytyczne WCAG (ang. Web Content Accessibility Guidelines) dotyczące dostępności zawartości serwisów www, zalecenia WAIARIA (ang. Accessible Rich Internet Application), będące opisem zasad i narzędzi służących do projektowania stron internetowych, zawierających dynamiczną zawartość, opartą na technologii AJAX [9].

Od podmiotów prowadzących własne serwisy internetowe wymaga się, aby były one dostępne na odpowiednim poziomie, co tym samym podlega ocenie. Może być ona przeprowadzana automatycznie przez różnego rodzaju specjalistyczne oprogramowanie lub manualnie, za pomocą technik, metod i narzędzi wykorzystywanych w audycie i ewaluacji serwisów (np. arkusze ocen, listy kontrolne, itp.) [9].

Badania dostępności serwisów uczelni wyższych były przedmiotem badań wielu prac [10-12]. W artykule [10] monitorowano strony uczelni medycznych w Iranie pod względem spełnienia przez nie potrzeb dla osób $\mathrm{z}$ niepełnosprawnościami. W badaniach użyto dwóch automatycznych narzędzi do oceny poziomu dostępności: AChecker i Functional Accessibility Evaluator (FAE). Pierwsze narzędzie zwracało liczbę rozpoznanych problemów, prawdopodobnych problemów oraz potencjalnych problemów. Drugie narzędzie generowało ocenę liczbową w zakresie od 0 do 100 dla pojedynczej strony. Za pomocą walidatora AChecker przebadano strony główne 50 uczelni, zaś narzędziem FAE przeanalizowano strony główne oraz po 25 podstron każdego z 50 serwisów uniwersytetów medycznych. Wyniki końcowe przedstawiono w tabeli, podając średnie ilości błędów oraz średnie oceny generowanej przez narzędzie FAE. Po wykonaniu analiz autorzy pracy doszli do wniosku, że dostępność zbadanych stron uczelni medycznych jest na niskim poziomie.

W kolejnej pracy [11] przeprowadzono badania dostępności stron WWW wśród osób całkowicie niewidomych. W tym celu został przygotowany prototypowy serwis internetowy zgodny ze standardem WCAG 2.0. Wykorzystano go w badaniach, w których wzięło udział 16 uczestników. Ich zadaniem było najpierw zapoznanie się z serwisem, a następnie udzielenie odpowiedzi na 14 pytań dotyczących dostępności serwisu. Wyniki z badań ankietowych przeprowadzonych komputerowo pogrupowano według czterech kryteriów, którymi były: postrzegalność, zrozumiałość, operatywność oraz interaktywność strony. Uśrednione wyniki złożyły się na końcową, wysoką ocenę dostępności prototypowego serwisu.

Autorzy artykułu [12] przeprowadzili porównanie dostępności treści edukacyjnych witryn internetowych wybranych uniwersytetów z Jordanii, Anglii oraz $\mathrm{z}$ regionu arabskiego. $\mathrm{W}$ badaniach skoncentrowano się na pomiarze zgodności stron www ze standardami dostępności dla osób niedowidzących. Najpierw badacze przestudiowali istniejące standardy, a następnie przea- 
nalizowali ich zastosowanie w serwisach internetowych instytucji edukacyjnych. Uzyskane wyniki pokazały, że liczba błędów dostępności stron uczelni $\mathrm{z}$ Jordanii i regionu arabskiego była odpowiednio 13 i 5 razy większa niż w Wielkiej Brytanii.

\section{Metoda badań}

W niniejszej pracy opracowano eksperyment, który składał się z dwóch części. Pierwsza część obejmowała analizę ekspercką przeprowadzoną na podstawie specjalnie do tego celu skonstruowanej listy kontrolnej, składającej się z 13 pytań dotyczących różnych mechanizmów dostępności, w które powinien być wyposażony dostępny serwis internetowy (Tabela 1). Odpowiedzi na te pytania miały charakter zero-jedynkowy.

Tabela 1: Lista kontrolna do oceny dostępności serwisów internetowych

\begin{tabular}{|c|l|}
\hline Lp. & \multicolumn{1}{|c|}{ Treść pytania } \\
\hline 1 & Czy serwis zawiera deklarację dostępności? \\
\hline 2 & Czy serwis umożliwia zmianę kontrastu? \\
\hline 3 & $\begin{array}{l}\text { Czy serwis zawiera mechanizmy zmiany kolorystyki } \\
\text { stron? }\end{array}$ \\
\hline 4 & $\begin{array}{l}\text { Czy w serwisie istnieje możliwość powiększenia } \\
\text { czcionki? }\end{array}$ \\
\hline 5 & $\begin{array}{l}\text { Czy serwis zawiera specjalne strony } \\
\text { dla osób niepełnosprawnych? }\end{array}$ \\
\hline 6 & Czy istnieje mobilna wersja serwisu? \\
\hline 7 & Czy dokumenty w formacie PDF są dostępne? \\
\hline 8 & $\begin{array}{l}\text { Czy możliwa jest nawigacja po serwisie za pomocą } \\
\text { klawiatury (klawisz TAB)? }\end{array}$ \\
\hline 9 & Czy serwis zawiera mapę i prostą wyszukiwarkę? \\
\hline 10 & $\begin{array}{l}\text { Czy serwis jest wyposażony w zaawansowaną wy- } \\
\text { szukiwarkę? }\end{array}$ \\
\hline 11 & $\begin{array}{l}\text { Czy formularze zawierają mechanizm sprawdzania } \\
\text { poprawności wprowadzanych danych? }\end{array}$ \\
\hline 12 & $\begin{array}{l}\text { Czy w przypadku multimediów (pliki audio, } \\
\text { filmy) możliwa jest kontrola odtwarzania? }\end{array}$ \\
\hline 13 & Czy multimedia (pliki audio, filmy) zawierają napisy? \\
\hline
\end{tabular}

W pierwszej części badań wzięło udział dwóch ekspertów znających problematykę dostępności. Ich zadaniem było zapoznanie się $\mathrm{z}$ ocenianym serwisem, a następnie podanie zero-jedynkowej odpowiedzi na pytania zawarte $\mathrm{w}$ liście kontrolnej. $\mathrm{W}$ ten sposób analizowane były wszystkie serwisy poddane ocenie dostępności. Uzyskane wyniki zostały następnie uśrednione.

Druga część eksperymentu, w której wykorzystano automatyczne narzędzia, składała się z trzech etapów:

- etap 1: ocena poziomu dostępności przez automatyczne narzędzie (wyrażona w postaci liczbowej),

- etap 2: ocena dokonywana na podstawie sumarycznej liczby wykrywanych przez dane narzędzie błędów,

- etap 3: ocena na podstawie analizy zdiagnozowanych typów błędów wykrytych podczas analizy każdej z siedmiu stron www danego serwisu.

Dla zobiektywizowania wyników postanowiono te same analizy powtórzyć za pomocą pięciu różnych, dobranych, automatycznych narzędzi, a z otrzymanych wyników obliczyć ocenę średnią. Wybór narzędzi został przeprowadzony na podstawie czterech kryteriów:
- analiza stron/serwisów www według standardu WCAG,

- bezpłatny dostęp (badanie pojedynczych stron lub całych serwisów),

- możliwość uruchomienia narzędzia w oknie przeglądarki (online),

- generowanie ogólnej oceny prezentowanej w postaci liczbowej (punktowej lub procentowej) wyrażającej poziom dostępności strony/serwisu.

Pierwszą fazę drugiej części eksperymentu zrealizowano za pomocą pięciu narzędzi: Lighthouse [13], ACE [14], MAUVE++ [15], FAE [16] oraz Utilitia [17]. Natomiast w drugiej i trzeciej fazie badań wykorzystano trzy narzędzia. Było to spowodowane problemami $\mathrm{z}$ dostępem do usługi MAUVE++ oraz pewnymi ograniczeniami narzędzia ACE.

\subsection{Material badawczy}

Analizę poziomu dostępności przeprowadzono na dziewięciu serwisach internetowych uczelni wyższych Lublina oraz dwóch czołowych uczelni w Polsce [18]. Badaniem były objęte serwisy następujących uczelni:

- $\quad$ Politechnika Lubelska (PL) [19]

- Uniwersytet Marii Curie-Skłodowskiej w Lublinie (UMCS) [20]

- Uniwersytet Przyrodniczy w Lublinie (UP) [21]

- Uniwersytet Medyczny w Lublinie (UM) [22]

- Katolicki Uniwersytet Lubelski (KUL) [23]

- Wyższa Szkoła Przedsiębiorczości i Administracji w Lublinie (WSPA) [24]

- Wyższa Szkoła Ekonomii i Innowacji w Lublinie (WSEI) [25]

- Wyższa Szkoła Nauk Społecznych z siedzibą w Lublinie (WSNS) [26]

- Wyższa Szkoła Społeczno-Przyrodnicza im. Wincentego Pola w Lublinie (WSSP) [27]

- Uniwersytet Warszawski (UW) [28]

- Uniwersytet Jagielloński (UJ) [29]

Serwisy dwóch ostatnich uczelni zawierają wydzielone działy, umieszczone w osobnej domenie i przeznaczone dla osób niepełnosprawnych. Również je poddano analizie pod kątem dostępności w ramach niniejszej pracy. Nazwy tych serwisów to:

- Dział ds. Osób Niepełnosprawnych Uniwersytetu Jagiellońskiego (UJ DON) [30]

- Biuro ds. Osób Niepełnosprawnych Uniwersytetu Warszawskiego (UW BON) [31]

Uznano, że badane będą ściśle określone pod względem tematycznym strony spośród wyżej wymienionych serwisów. Wybrano siedem, następujących podstron:

- $\quad$ strona główna uczelni,

- strona z danymi do kontaktu,

- strona główna rekrutacji,

- $\quad$ strona główna biblioteki,

- $\quad$ strona aktualności prezentująca najnowszą wiadomość,

- podstrona z informacjami dla studentów, 
- strona Biura Kształcenia Międzynarodowego (BKM) lub strona $\mathrm{z}$ informacjami o programie Erasmus.

Podczas badań okazało się, że nie wszystkie serwisy zawierały wyżej określony zestaw stron.

\subsection{Narzędzia do badania dostępności stron inter- netowych}

W pracy wykorzystano metodę opartą na analizie eksperckiej wspartej analizą przeprowadzoną za pomocą automatycznych narzędzi. W ocenie eksperckiej wykorzystana została lista kontrolna. Do analizy automatycznej zostały wybrane narzędzia, które spełniały wymagania zdefiniowane przez autorów. Wśród tych narzędzi znalazły się: Lighthouse, ACE (Accessibility Evaluator), MAUVE++, FAE (Functionality Accessibility Evaluator) oraz Utilitia. Pierwsze trzy programy badają pojedynczą stronę serwisu i zwracają wynik w postaci liczbowej w zakresie od 0 do 100 . Ostanie narzędzie ma możliwość badania pojedynczej strony lub całego serwisu i również zwraca wynik z zakresu od 0 do 10.

\section{Wyniki badań}

\subsection{Ocena ekspercka}

$\mathrm{Na}$ pierwszą część eksperymentu składały się badania, które miały odpowiedzieć na pytanie „Jaki poziom dostępności mają badane serwisy uczelni, biorąc pod uwagę zawarte w nich funkcjonalności, które dotyczyły aspektów dostępności?”. W badaniu wzięło udział dwóch niezależnych ekspertów, których zadaniem była najpierw analiza stron internetowych, a następnie wypełnienie list kontrolnych dla każdego badanego serwisu. Odpowiedzi obu specjalistów były w stu procentach zgodne. Rysunek 1 ilustruje uzyskane wyniki. Na osi pionowej prezentowany jest odsetek serwisów uczelni zawierających daną funkcjonalność odnoszącą się do kwestii dostępności.

Tylko jeden z dwóch analizowanych tzw. dostępnych serwisów - UW BON, posiadał wymaganą deklarację dostępności. Natomiast żaden z pozostałych serwisów ujętych w badaniach takiego dokumentu nie posiadał. Większość serwisów uczelni (64\%), w tym oba serwisy dostępne, umożliwia zmianę kontrastu.

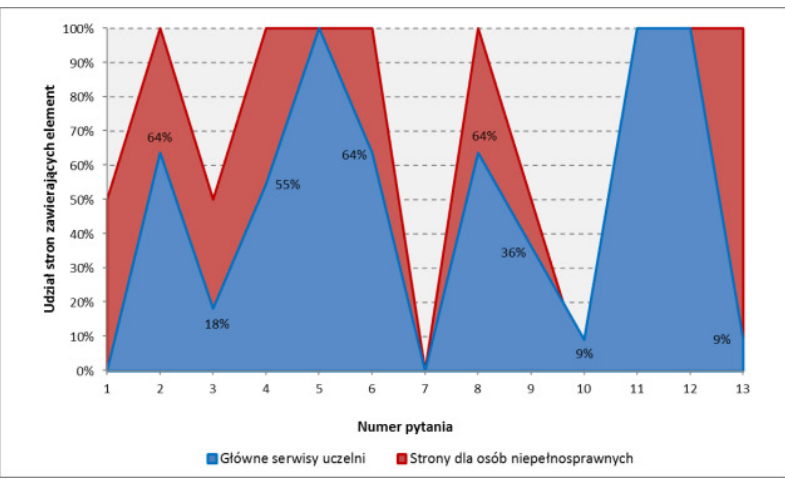

Rysunek 1: Udział serwisów zawierających daną funkcjonalność mającą bezpośredni wpływ na poziom dostępności.

Tylko dwa serwisy uczelni umożliwiają zmianę kolorystyki stron, co dało $18 \% \mathrm{w}$ grupie ogólnodostęp- nych, tzn. oficjalnych i 50\% w grupie serwisów dostępnych. 55\% serwisów ogólnodostępnych i 100\% serwisów dostępnych daje możliwość powiększenia wielkości czcionki. Wszystkie spośród z badanych serwisów uczelni wyższych posiadają specjalne strony, zawierające informacje dla osób niepełnosprawnych. Ponad połowa serwisów zawiera wersję mobilną, co stanowi około $64 \%$. Niestety udostępniane na stronach badanych serwisów pliki PDF nie spełniają kryteriów dostępności. W przypadku $64 \%$ podstawowych serwisów, możliwa jest ich obsługa za pomocą klawiatury. Również oba serwisy dostępne posiadają taką możliwość. 36\% serwisów podstawowych zawiera mapę strony i prostą wyszukiwarkę. Tylko jeden z dwóch serwisów dostępnych posiada proste narzędzie wyszukiwawcze. Wyszukiwarkę zaawansowaną miał wbudowaną tylko serwis UMCS. Formularze znajdujące się na stronach uczelni, są wyposażone w mechanizm walidacji poprawności danych. Również wszystkie strony uczelni miały mechanizm kontroli odtwarzania multimediów. Tylko serwis UW BON zawiera filmy, które wyświetlają napisy podczas ich oglądania.

\subsection{Ilościowa ocena dostępności za pomocą narzę- dzi automatycznych}

W pierwszej fazie drugiej części eksperymentu dokonano oceny każdej z siedmiu stron internetowych danego serwisu uczelni za pomocą pięciu narzędzi, które zwracały wynik w postaci liczbowej. Na Rysunku 2, oś Y prezentuje średnie poziomy dostępności serwisów poszczególnych uczelni. Z wykresu tego wynika, że serwisy dostępne UW BON i UJ DON mają najwyższe poziomy dostępności na tle serwisów uczelni z Lublina. Podobny, wysoki poziom dostępności, wynoszący około $73 \%$, osiągnęły również serwisy KUL oraz UJ. Natomiast najniższe średnie oceny (poniżej 60\%) miały serwisy czterech uczelni: PL, UP, WSNS oraz WSSP.

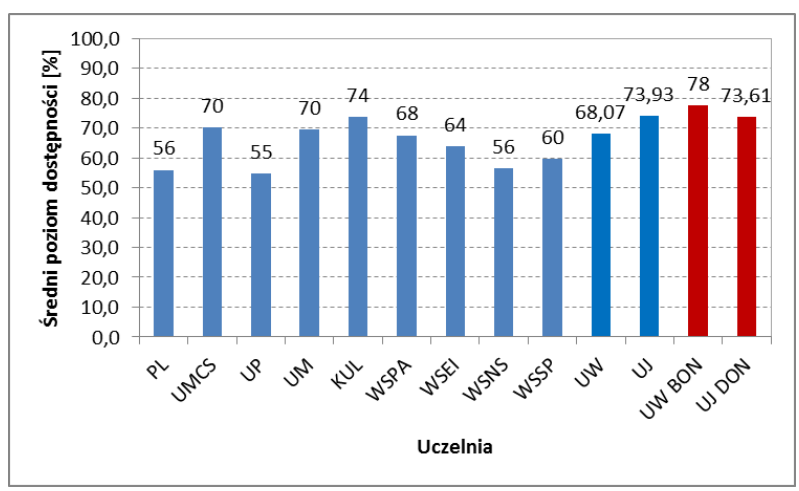

Rysunek 2: Średni poziom dostępności serwisów wybranych uczelni według automatycznych narzędzi.

Rysunek 3 przedstawia z kolei oceny dostępności serwisów uczelni wygenerowane przez każde $\mathrm{z}$ osobna z czterech narzędzi (bez MAUVE++, które uległo awarii). $Z$ wykresu tego wynika, że zdecydowanie najniższe oceny wystawiało narzędzie FAE (w granicach od 19,20 $\%$ do $42,67 \%$ ). Natomiast oceny podawane przez narzędzia ACE oraz Lighhouse były wyższe od średniej oznaczonej na wykresie czerwoną linią. Narzędziem, 
które w większości przypadków generowało wyniki najbardziej zbliżone do średniej było Utilitia.

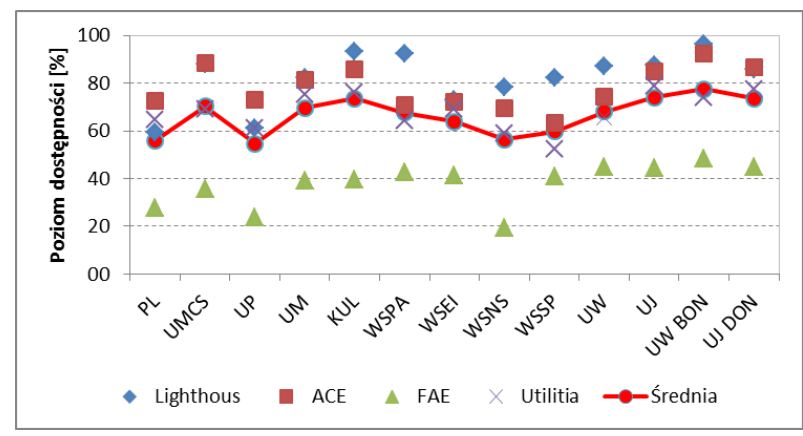

Rysunek 3: Poziom dostępności serwisów uczelni zrealizowany za pomocą automatycznych narzędzi.

$\mathrm{Na}$ Rysunku 4 zobrazowano wyniki analizy serwisów uczelni wyższych wykonane za pomocą narzędzia Utilitia. Warto zaznaczyć, że tylko ta aplikacja dawała możliwość jednoczesnego przebadania całych serwisów. W pozostałych przypadkach analizowane były osobno poszczególne strony. W badaniu zrealizowanym tym narzędziem serwisy: UJ i UJ DON osiągnęły najwyższe wyniki - odpowiednio na poziomie $83 \%$ i $84 \%$.

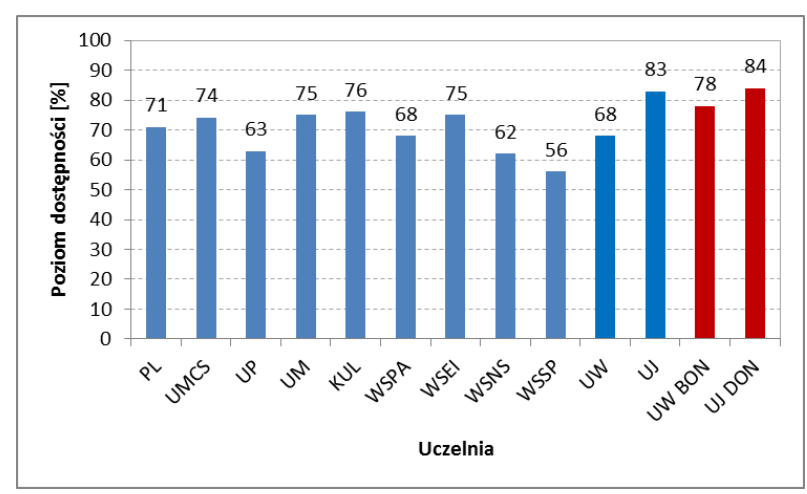

Rysunek 4: Poziom dostępności serwisów uczelni wyższych wykonany za pomocą narzędzia Utilitia (analiza całego serwisu).

Na Rysunku 5 zaprezentowano poziomy dostępności dla siedmiu podstron przebadanych za pomocą czterech narzędzi.

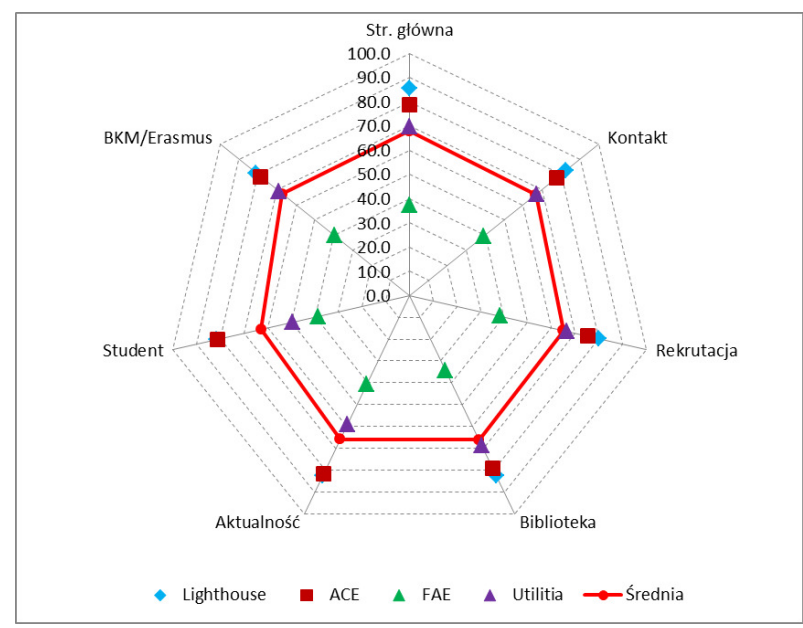

Rysunek 5: Oceny dla poszczególnych siedmiu stron wygenerowane przez automatyczne narzędzia.
Warto zauważyć, że średni poziom dostępności badanych stron, który graficznie przedstawia czerwona linia, jest na bardzo zbliżonym poziomie i oscyluje w granicach $60 \%-70 \%$. Najwyższe wyniki generowały narzędzia Lighthouse oraz ACE, a najniższe FAE.

\subsection{Analiza całkowitej liczby błędów dostępności zdiagnozowanych przez automatyczne narzę- dzia}

Rysunek 6 pokazuje liczbę błędów wykrytych przez trzy narzędzia w przebadanych stronach serwisów uczelni. Najwięcej problemów wykrywało narzędzie Utilitia i w przeważającej mierze występowały one w arkuszu stylów. Trzeba tu zaznaczyć, że poszczególne narzędzia inaczej klasyfikują błędy. Według narzędzia Utilitia najwięcej błędów zostało wykrytych w trzech serwisach: WSPA, WSEI oraz WSSP. Z kolei według narzędzia FAE najwięcej błędów znajdowało się w serwisie WSNS, a najmniej w serwisie UW BON. Narzędzie Lighthouse wykryło najwięcej błędów w serwisach: UJ DON, UJ i UW, a najmniej w UW BON oraz KUL.

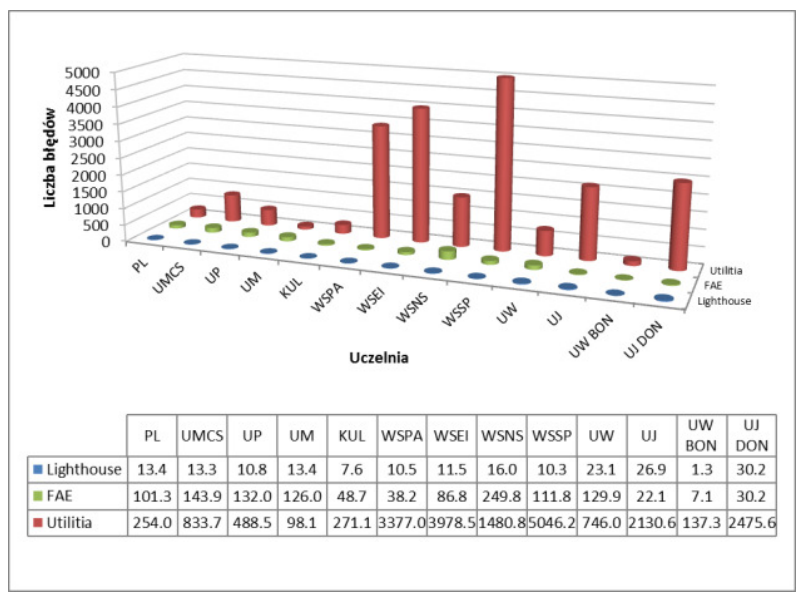

Rysunek 6: Średnia liczba błędów dla stron serwisów poszczególnych uczelni wykryta przez automatyczne narzędzia do badania dostępności.

\subsection{Klasyfikacja wykrytych błędów przez automa- tyczne narzędzia}

W trzecim etapie badań wyznaczono udział poszczególnych rodzajów błędów występujących w badanych serwisach uczelni. Rysunek 7 pokazuje jakie typy błędów zostały wykryte przez narzędzie Utilitia. Najliczniejszymi dwoma grupami błędów były te, które dotyczyły walidacji plików CSS i HTML i stanowiły odpowiednio $75,35 \%$ i $22,54 \%$ wszystkich błędów. Trzecią grupą były błędy związane z dostępnością linków. Ich odsetek wynosił $1,12 \%$.

Biorąc pod uwagę wszystkie analizowane serwisy uczelni, średnie liczby błędów dla poszczególnych stron internetowych wybranych do badań zdiagnozowane przez narzędzie Utilitia zostały przedstawione na Rysunku 8. Z wykresu wynika, że najwięcej błędów wystąpiło na stronach BKM/Erasmus, natomiast najmniej błędów odnotowano na stronach $\mathrm{z}$ informacjami dla studentów. 


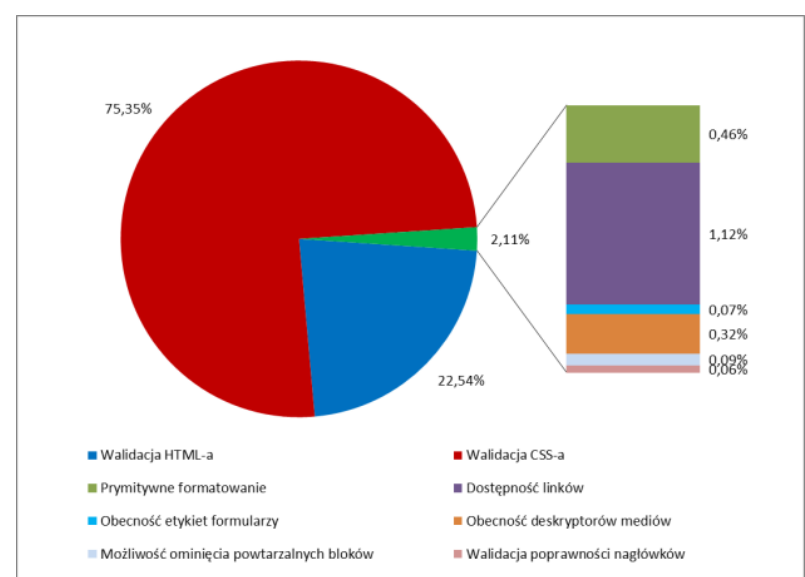

Rysunek 7: Udział poszczególnych typów błędów występujących w serwisach uczelni zdiagnozowanych za pomocą narzędzia Utilitia.

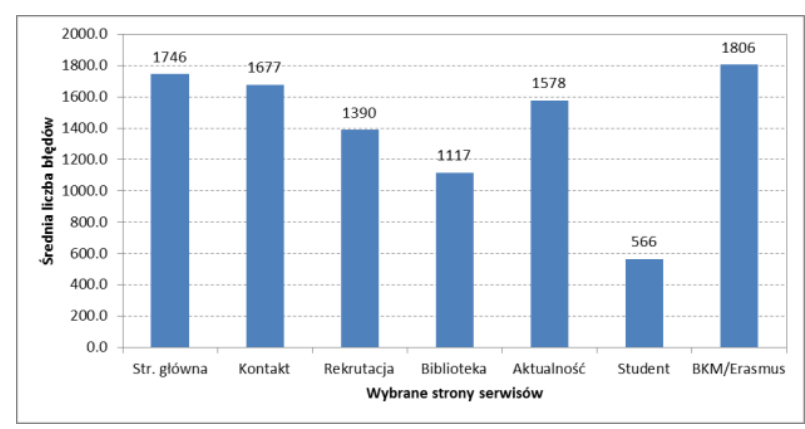

Rysunek 8: Średnia liczba błędów poszczególnych stron serwisów uczelni według narzędzia Utilitia.

$\mathrm{Z}$ kolei narzędzie FAE wykryło osiem rodzajów błędów. Największy odsetek, bo aż $65,27 \%$, stanowiły błędy związane $\mathrm{z}$ adaptowalnością. Na drugim miejscu $(7,75 \%)$ sklasyfikowano błędy dotyczące rozpoznawalności, a na trzecim $(7,11 \%)$ błędy dotyczące nawigowalności (Rysunek 9).

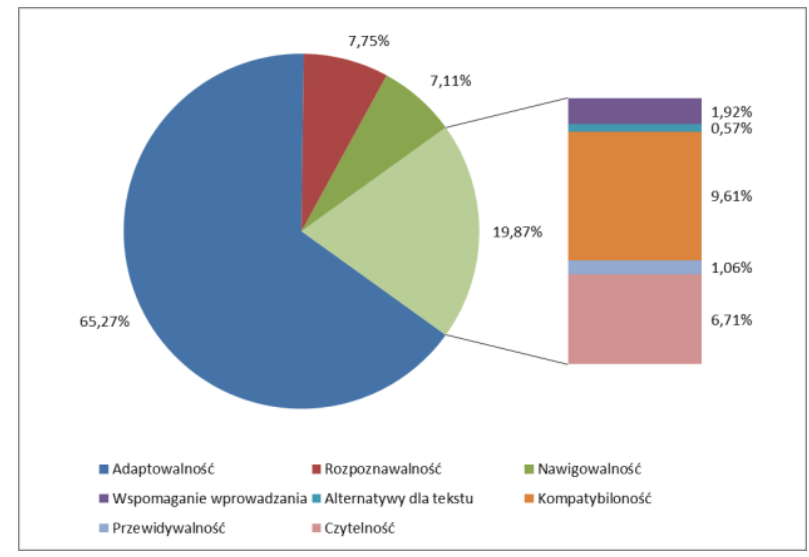

Rysunek 9: Udział poszczególnych typów błędów w badanych serwisach uczelni według narzędzia FAE.

Na Rysunku 10 pokazano, ile średnio na wybranych do badań stronach serwisów wszystkich uczelni wykryto błędów za pomocą narzędzia FAE. Z wykresu tego widać, że średnia ta jest znacznie niższa od średniej liczby błędów wykrytych przez Utilitię. Najwięcej błędów zostało wykrytych na stronie głównej (104), a najmniej na stronach BKM/Erasmus (65) oraz stronach z informacjami dla studentów (65).

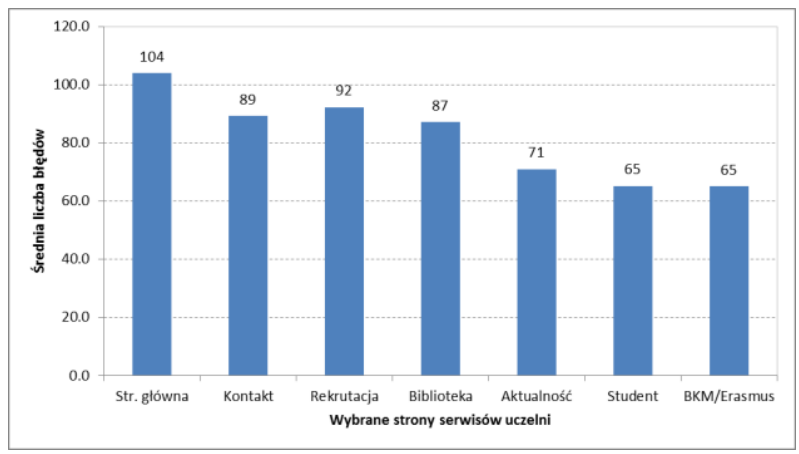

Rysunek 10: Średnia liczba błędów poszczególnych stron serwisów uczelni według narzędzia FAE.

Na Rysunku 11 zaprezentowano udział poszczególnych typów błędów, jakie zostały wykryte za pomocą narzędzia Lighthouse. W tym przypadku wykryto sześć typów błędów, które były związane z takimi elementami jak: kontrast, nazwy i etykiety, umiędzynarodowienie i lokalizacja, nawigacja, tabele i listy oraz ARIA. Najwięcej błędów było związanych z kontrastem (42\%) oraz z nazwami i etykietami (29\%). Trzecią pod względem wielkości grupą błędów były błędy w nawigacji. Stanowiły one $18 \%$ wszystkich błędów.

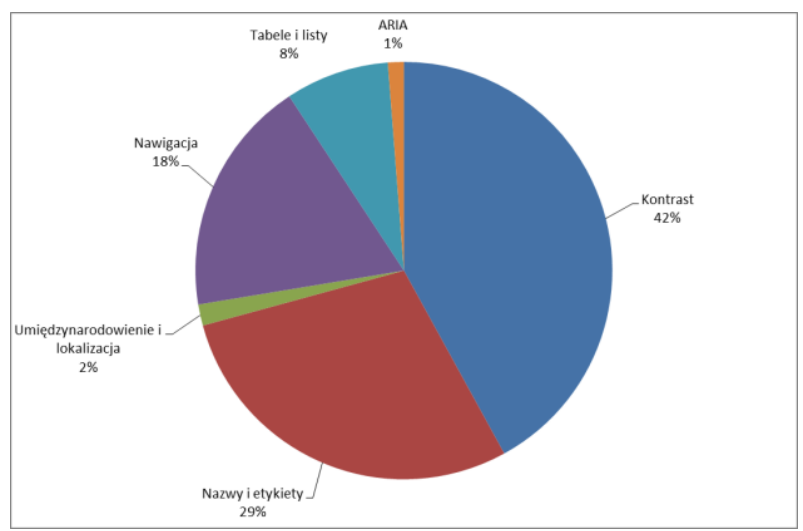

Rysunek 11: Udział poszczególnych typów błędów w serwisach uczelni według narzędzia Lighthouse.

Rysunek 12 przedstawia średnie liczby błędów dla poszczególnych stron spośród wszystkich serwisów uczelni wykrytych przez Lighthouse. W tym przypadku warto zauważyć, że średnie liczby wykrytych błędów są na niskim poziomie, wynoszącym mniej niż 20 błędów.

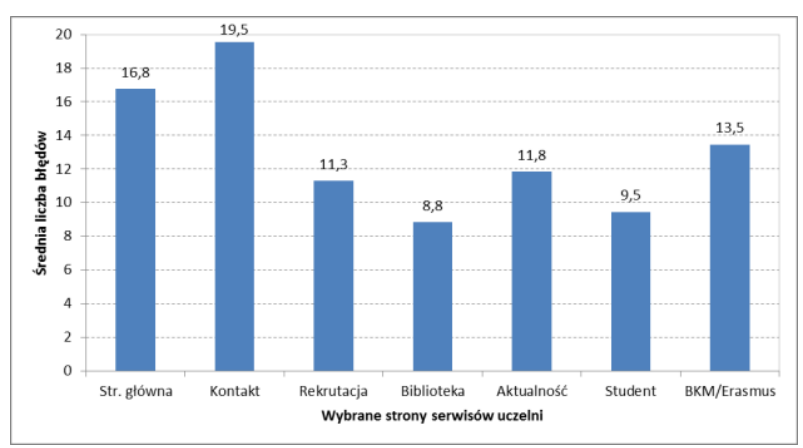

Rysunek 12: Średnia liczba błędów poszczególnych stron serwisów uczelni według narzędzia Lighthouse. 


\section{Wnioski}

Dostępność serwisów uczelni wyższych ma obecnie duże znaczenie, gdyż zgodnie z prawem z 2020 roku publiczne instytucje szkolnictwa wyższego są zobligowane do uczynienia swoich serwisów dostępnymi, tzn. spełniającymi kryteria opisane w standardzie WCAG 2.1 na poziomie AA. Na podstawie wyników przedstawionych $\mathrm{w}$ poprzednim rozdziale, można stwierdzić, że przed uczelniami jest jeszcze wiele pracy, prowadzącej do zapewnienia odpowiedniego poziomu dostępności serwisów www. Podjęcia działań wymagają głównie następujące kwestie:

- $\quad$ sporządzenie i umieszczenie w serwisie deklaracji dostępności,

- opracowywanie dostępnych plików PDF,

- dodanie mechanizmu zmiany kolorystyki stron,

- wykonanie mobilnej wersji serwisu.

Badania zrealizowane w ramach tej pracy, oparte były na opracowanej metodzie wyznaczającej poziom dostępności serwisów, wykorzystującej automatyczne narzędzia oraz listę kontrolną składającą się z 13 pytań. Uzyskane wyniki pokazały, że poziom dostępności serwisów niektórych uczelni Lublina jest niski, szczególnie w porównaniu z serwisami dwóch najlepszych uczelni w Polsce. Uczelnie UJ i UW w ramach swoich serwisów mają wydzielone podserwisy skierowane do osób ze specjalnymi potrzebami. Można powiedzieć, że te specjalne serwisy wyróżniały się zdecydowanie wyższymi poziomami dostępności na tle serwisów innych uczelni, które były badane.

Opierając się na zdobytym doświadczeniu podczas opracowania i realizacji eksperymentu można wysnuć ogólny wniosek, że badanie i ocena dostępności stron www jest zadaniem trudnym i skomplikowanym. Posługując się automatycznymi narzędziami należy pamiętać, że każde z nich w odmienny sposób podchodzi do różnych aspektów dostępności. Z kolei podczas analizy eksperckiej zastosowano pewne uproszczenia i skoncentrowano się wyłącznie na podstawowych kwestiach dostępności, pomijając te, które według autorów były mniej ważne. Należy również zauważyć, że pewnym ograniczeniem tej pracy jest czas przeprowadzenia badań, które zostały zrealizowane we wrześniu 2020 roku i do momentu publikacji tego artykułu omawiane serwisy mogły ulec modernizacji i w związku z tym ich poziom dostępności mógł także się zmienić.

\section{Literatura}

[1] M. Miłosz, Ergonomia systemów informatycznych, Politechnika Lubelska, 2014, http://www.bc.pollub.pl/ dlibra/publication/9004/edition/8718, [20.08.2020].

[2] W3C, Supported States and Properties, http://www.w3.org/WAI/intro/accessibility.php, [20.08.2020].

[3] B. Wit, Dostępność zawartości w serwisach WWW przedsiębiorstw przemysłowych, Technologie internetowe - od teorii do praktyki, Polskie Towarzystwo Informatyczne, Warszawa 2008, https://pti.cs.pollub.pl/wp-content/uploads/2018/06/ Technologie-internetowe2008.pdf, [20.08.2020].
[4] Dyrektywa Parlamentu Europejskiego i Rady (UE) 2016/2102 z dnia 26 października 2016 r. w sprawie dostępności stron internetowych i mobilnych aplikacji organów sektora publicznego (Dziennik Urzędowy Unii Europejskiej L 327/1,2.12.2016 ).

[5] Dostępność cyfrowa. Omówienie wymogów dostępności cyfrowej dla podmiotów publicznych, https://www.gov.pl/web/dostepnosc-cyfrowa/omowieniewymogow-dostepnosci-cyfrowej-dla-podmiotowpublicznych, [20.08.2020].

[6] Ustawa z dnia 4 kwietnia 2019 r. o dostępności cyfrowej stron internetowych i aplikacji mobilnych podmiotów publicznych (Dz. U. 2019 poz. 848).

[7] D. Paszkiewicz, J. Dębski, Dostępność serwisów internetowych. Dobre praktyki w projektowaniu serwisów internetowych dostępnych dla osób z różnymi niepełnosprawnościami, Stowarzyszenie Przyjaciół Integracji, Warszawa, 2013, https://www.power.gov.pl/ media/13588/Dostepnosc-serwisow-internetowychDominik-Paszkiewicz-Jakub-Debski.pdf, [20.08.2020].

[8] Essential Components of Web Accessibility, http://www.w3.org/WAI/intro/components.php, [20.08.2020].

[9] B. Wit, D. Kuś, M. Malendowski, System informatyczny GeoAzbest. Zintegrowany system zarządzania, Wydawnictwo „Dom Orgganizatora”, Toruń, 2013, http://bc.pollub.pl/Content/8644/PDF/4-system.pdf, [20.08.2020].

[10] S. Rahmatizadeh, S. Valizadeh-Haghi, Monitoring for accessibility in medical university websites: Meeting the needs of people with disabilities, Journal of Accessibility and Design for All, 8 (2), (2018) 102-124, , http://www.jacces.org/index.php/jacces/article/view/150/ 201, [20.08.2020].

[11] M. S. Hassouna, N.Sahari, A. Ismail, University website accessibility for totally blind users, Journal of Information and Communication Technology, 16 (1) (2017) 63-80,

http://e-journal.uum.edu.my/index.php/jict/ article/view/8218/1236, [22.08.2020]

[12] B. Abu Shawar, Evaluating Web Accessibility of Educational Websites, International Journal of Emerging Technology in Learning, 10 (4), (2015), https://onlinejournals.org/index.php/i-jet/article/view/4518/3582, [20.08.2020].

[13] Lighthouse, https://developers.google.com/web/tools/lighthouse, [20.09.2020].

[14] Accessibility Evaluator https://ace.accessibe.com/, [20.09.2020].

(ACE),

[15] Multiguideline Accessibility and Usability Validation Environment (MAUVE++), https://mauve.isti.cnr.it/, [20.09.2020].

[16] Functional Accessibility Evaluator 2.1 (FAE), https://fae.disability.illinois.edu/anonymous/?Anonymous \%20Report=, [20.09.2020].

[17] Utilitia, https://utilitia.pl, [20.09.2020]. 
[18] Ranking Uczelni Akademickich 2020, http://ranking.perspektywy.p1/2020/ranking/rankinguczelni-akademickich, [20.09.2020].

[19] Serwis Politechniki Lubelskiej, http://www.pollub.pl, [20.09.2020].

[20] Serwis Uniwersytetu Marii Curie-Skłodowskiej, https://www.umcs.pl, [20.09.2020].

[21] Serwis Uniwersytetu Przyrodniczego w Lublinie, https://www.up.lublin.pl, [20.09.2020].

[22] Serwis Uniwersytetu Medycznego w Lublinie, https://www.umlub.pl, [20.09.2020].

[23] Serwis Katolickiego Uniwersytetu Lubelskiego, https://www.kul.pl, [20.09.2020].

[24] Serwis Wyższej Szkoły Przedsiębiorczości i Administracji w Lublinie, https://wspa.pl, [20.09.2020].
[25] Serwis Wyższej Szkoły Ekonomii i Innowacji w Lublinie, https://www.wsei.lublin.pl, [20.09.2020].

[26] Serwis Wyższej Szkoły Nauk Społecznych w Lublinie, https://www.wsns.lublin.pl, [20.09.2020].

[27] Serwis Wyższej Szkoły Społeczno-Przyrodniczej im. Wincentego Pola w Lublinie, https://wssp.edu.pl, [20.09.2020].

[28] Serwis Uniwersytetu Warszawskiego, https://www.uw.edu.pl, [20.09.2020].

[29] Serwis Uniwersytetu Jagiellońskiego, https://www.uj.edu.pl, [20.09.2020].

[30] Serwis Działu ds. Osób Niepełnosprawnych Uniwersytetu Jagiellońskiego, https://don.uj.edu.pl, [20.09.2020].

[31] Serwis Biura ds. Osób Niepełnosprawnych Uniwersytetu Warszawskiego, https://bon.uw.edu.pl, [20.09.2020]. 